A reply to R. Hueting's article in ÖkologischesWirtschaften 04/2011

\section{Environmentally sustainable national income: Work in progress}

The calculation of the environmentally sustainable national income is not only relatively easy, it is also the best measure compared to other comparable alternative indices. The index deserves more attention because it is a useful scientific tool to provide society with essential information to decide upon future strategies of economic policy.

By Thomas Colignatus

n ÖkologischesWirtschaften 04/2011 Hueting proposes a change of method at the national statistical bureau's and the agencies for the evaluation and forecasting of economic policy (Hueting 2011). First, the figure of national income (NI) can be adapted for asymmetric bookkeeping. Secondly, we can create the figure of environmentally sustainable national income (eSNI). The gap between NI-exasyms and eSNI indicates whether the world becomes grayer or greener.

Colignatus discusses Hueting's intellectual path. Some selected comments could put Hueting's paper in more perspective (Colignatus 2009).

\section{A relatively cheap correction}

A new reader might think that the calculation of eSNI is expensive. The cost of modelling and collection of all these ecological data might seem prohibitive. However, the relevant data are collected already for normal policy making. Governments already need to keep track of clean air and water, and so on.

The eSNI calculation is only a relatively small modelling exercise at the top of the pyramid of the integration of statistical indicators. At Statistics Netherlands the costs were only 0.25 percent of its budget. Such a cost can be quite acceptable for such an important indicator.

The power of Hueting's analysis is that it is embedded both in the tradition of economic theory and established procedures on economic statistics. The world has a huge machine of statistics, e.g. the Statistical Commission of the United $\mathrm{Na}$ tions. Hueting's contribution to the environmental statistics base of the System of Environmental-Economic Accounts of the United Nations is already well accepted. This machine only requires a small nudge to start producing the figure for eSNI too.

\section{The need for some focus}

This small nudge doesn't yet come about because of a mere lack of focus by all actors involved. The prime problem is that people don't study Hueting's work. Perhaps some of his scientific statements trigger the wrong reactions or push the wrong buttons. But the statements are grounded in economic theory and statistical practice, and there is no other way than use those precise words. Readers concerned about economics and the environment are advised to study Hueting's work to resolve their misgivings.

\section{Distracting temptations}

One problem is that statisticians observe the present while sustainability refers to the future. If Hueting had worked at a forecasting bureau he would have developed an analysis on the future, and the statistical component would have been a corollary. Now Hueting worked at Statistics Netherlands and developed the proper statistical approach, namely eSNI depends upon assumptions on preferences of present people about the future.
Now the future is a corollary. The difference is immaterial. But it may take an additional round of explanation.

Hueting's analysis has long fallen into a gap between economists who neglected the environment and environmentalists who disliked economics. Now that the world can actually observe how the climate is changing, there is more attention for environmental economics. Still, there are all kinds of indicators, like the footprint, genuine progress, et cetera, that destroy focus. Statisticians aren't front page people and may not be adequately noticed by professors at the academia who want to have their publications. The front page statistician by exception is Bjørn Lomborg but he does not refer to Hueting's work.

Recently there is a lot of attention for happiness, but ecological survival is a prerequisite that then apparently is neglected. Authors on happiness could be advised to focus on getting eSNI accepted first amongst economists, statisticians, policy makers and the general public, who currently are quite misled by using only national income.

One group of researchers proposes to abolish NI altogether but it would seem that this kind of academic discussion is better done while NI and eSNI are smoothly running in the background. Governments needed a figure like NI since they needed more overview to manage our ever more complex societies. NI has been hugely beneficial. But the new scarcity of the ecology requires an adaptation in this method, so simple is the issue.

\section{How to do science}

Hueting's work can be understood in the tradition of Leibniz with the spirit „Let us sit down and look at the formula's“ (no quote). NI is well-developed but still work in progress and the latter also holds for eSNI. The work and results are scientifically warranted because of this attitude. Who reads Hueting's work notes that he personally cares about the environment but also how he focuses on what is scientifically warranted. The role of the scientist is to provide information, and it is up 
to democratic society to decide. If society doesn't have the proper information however it can only guess at its policy and instruments. Thus the scientific ethic of creating the required information is essential.

Over the last decades, the Anglo-Saxon method of the debating society has grown in prominence. In a world of uncertainty, let the best debater win, is the idea. A recent book by Stephen Schneider is titled „Science as a contact sport“. My suggestion is to be open-minded. Debating can be enlightening but Leibniz better has the last word. I am regularly amazed how often people did not sit down and study the formulas. The story of Global Warming is not only about a world economy spinning out of control but also about scientific mores. Let us learn from these decades.

\section{Work in progress}

As said, NI and eSNI are work in progress. Some critical points for the modelling in eSNI are:

- Environmentally sustainable national income doesn't include yet the competing use of space, for example for plants and wild life, nor the costs for the development and use of alternative resources.

- The physical norms for sustainability are based upon judgment and thus are open to criticism, uncertainty and scientific progress.

- The estimates of price and income elasticity in demand and supply functions rely on current conditions. Those will change in a process towards sustainability, but yet unknown how.

- Environmentally sustainable national income uses comparative statics. A dynamic model would give a transition path from one state to the other, with an influence of policy instruments on the speed of adjustment.

- An eSNI for one country assumes that all countries adopt sustainability, otherwise there will only be a relocation of the burden on the environment. In practice policies will differ with different effects on eSNI. A pilot for e.g.
Germany and Holland would show how large the effects could be.

\section{References}

Colignatus, T.: The Old Man and the SNI. A review of advance and adversity in Hueting's research in sustainable national income (SNI), economic growth and the new scarcity from the environment. München 2009. Internet: http://mpra.ub.uni-muenchen.de/12690

Hueting, R.: The future of the Environmentally sustainable national income.

In: ÖkologischeWirtschaften 4/2011. S. 30-35

Der verborgene Reichtum

Warum sind Norweger und Schweizer nicht nur wirtschaftlich, sondern auch sozial so erfolgreich? Wie kann Deutschland seine Schuldenkrise überwinden oder seine Arbeitslosigkeit abbauen? Das Buch zeigt auf, wie Gemeinschaften durch die Mobilisierung ihres Sozialkapitals ohne Geld Werte schaffen, um ihre Probleme mit nicht materiellen Ressourcen zu lösen. Ein Plädoyer für mehr Mit- statt Gegeneinander, für Werte wie Vertrauen, Hilfsbereitschaft und Gastfreundschaft.

\section{A. Dill}

\section{Gemeinsam sind wir reich}

Wie Gemeinschaften ohne Geld Werte schaffen

208 Seiten, broschiert, 14,95 Euro, ISBN 978-3-86581-288-9

\section{/III oekom}

Die guten Seiten der Zukunft

Erhältlich bei www.oekom.de

I AUTHOR + CONTACT

Thomas Colignatus is the name in science of Thomas Cool. Thomas Cool works as econometrician in Scheveningen, Netherlands.

E-Mail:cool@dataweb.nl oekom@verlegerdienst.de

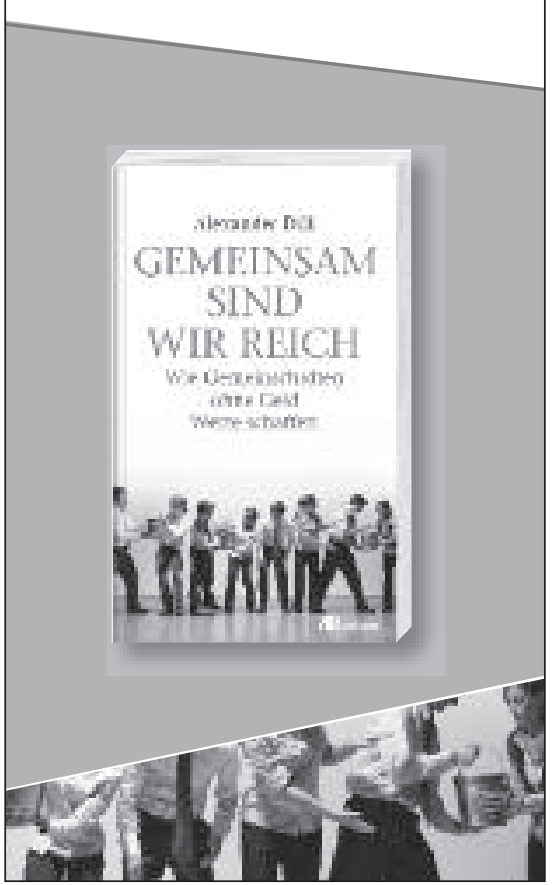




\section{Lizenzhinweis}

Die Beiträge in ÖkologischesWirtschaften werden unter der Creative-Commons-Lizenz "CC 4.0 Attribution Non-Commercial No Derivatives" veröffentlicht. Im Rahmen dieser Lizenz muss der Autor/Urheber stets genannt werden, das Werk darf nicht bearbeitet, abgewandelt oder in anderer Weise verändert und außerdem nicht kommerziell genutzt werden. Die digitale Version des Artikels bleibt für zwei Jahre Abonnent/innen vorbehalten und ist danach im Open Access verfügbar. 